\title{
Organizational Citizenship Behaviors In Relation To Job Embeddedness, Organizational Identification, Job Performance, Voluntary Turnover Intention In Korea.
}

Young-bohk Cho, Pusan National University, Korea

Jeong-ran Ryu, Pusan National University, Korea

\begin{abstract}
The purpose of this article is to do determine whether the positive or the negative association between Organizational Citizenship Behaviors and Job Embeddedness, Organizational Identification, Job Performance, Voluntary Turnover Intention in Korea. At Present, the organizational costs of leaving a job are often very high. It is not surprising, then, that employee retention has the attention of top-level managers in today's organizations. Recently, Mitchell, Holtom, Lee, Sablyski, and Erez(2001) focused on why people stay rather than on how they leave. In particular, they drew attention to the reasons people stay through their job embeddedness construct. They aggregated job embeddedness correlated with intention to leave and predicted subsequent voluntary turnover. More recently, According to Lee, Mitchell, Sablynski, Burton \& Holtom(2004), job embeddedness was disaggregated into its two major subdimensions, on-the-job (that is, organizational fit, links, and sacrifice) and off-the-job embeddedness (that is, community fit, links, and sacrifice). They revealed that off-the-job embeddedness was significantly predictive of subsequent "voluntary turnover". Also, they revealed that on-the-job embeddedness was significantly predictive of organizational citizenship. They predicted that employee withdrawal occurs over time, with a decision about performing preceding a decision about participating. On the basis of situational and theoretical backgrounds as above, the purpose of this study is to examine the relationship between on-the-job embeddedness and job performance, voluntary turnover intention, organizational identification in Korean employees and the mediating effect of organizational citizenship behavior in that relationship. To empirical study for test a model as above, 300 structured questionnaires were distributed to Korean employees in Seoul, Busan, and Gyeongnam, Korea. 255 were finally analyzed. The results revealed that individuals' fit, links to the organization and organization-related sacrifice significantly had negative effects on voluntary turnover intention and positive effects on job performance, organizational identification and that Organizational citizenship behavior mediated the relationship between on-the-job embeddedness and job performance, voluntary turnover intention, organizational identification. Implications for managers in organizations are suggested.
\end{abstract}

\section{INTRODUCTION}

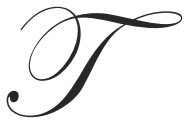

he source of competitiveness generated from human resource development at the knowledge-based information society in the 21-st century. It is that competitiveness of all organizations which is composing this society such as the country and area and corporation is decided according to systematic knowledge management and creation, practice. Therefore, the importance of human resource development that take charge of management, creation, practice to knowledge should be emphasized. So, in the Future, most important resource of organization is the talented human resources who possess predictability to global environment and competitiveness. General demand about corporation's human resource will be fluctuation, but competition about superior human resources's security may be violent. 
Korea made to leave many employees because there are much restructurings bringing big change in organization since the IMF economic crisis in situation that is emphasized to the importance of superior human resources's security, and so, individuals were faced on particular situation that is collapsed to the place of work at lifelong. Unlike past, many employees select voluntary and actively turnover. Also, more and more it is made as an opportunity for own career development. Already, some employees choose voluntary resignation to age of 30 with reemployment possibility.

Such voluntary turnover can become a new opportunity such as career development to individual, but voluntary turnover of excellent employees causes fairly expensive damage in organization. As well as, security and preservation, development of the talented human resources will be dominate that company's life and death at the age of limitless competition.

So far, research about cause of really voluntary turnover executed actively, but there is seldom research about cause that do so that employee may remain within organization. Therefore, this research wishes to focus on some method to solidify competitive power through that organization keeps the talented human resource.

So, this study is begun under expectation which improvement of job embeddedness that is concept that explain why employees are remained within organization may bring improvement of organizational citizenship behavior. Then, employee's risen job embeddedness makes reason that employee must remain within organization strongly. And this may bring satisfaction and commitment to organization and it is going to bring satisfaction both organizational life and individual life. Similarly, it may become an opportunity of organizational development through that keep satisfied employees' job commitment and high performance and human capital of high level in organization. Finally, it may also contribute more to organizational effectiveness.

The present research was designed to examine the relation between organizational citizenship behaviors and job embeddedness, organizational identification, job performance, voluntary turnover intention as following.

- First, this study examine relationship between organizational citizenship behavior that influence on organizational security, preservation, growth and a level of employee's on-the-job embeddedness.

- $\quad$ Second, this study examine relationship between the level of employee's organizational citizenship behavior and job performance, voluntary turnover intention, organizational identification.

- $\quad$ Third, this study examine the mediating effect of employee's organizational citizenship behavior between job embeddedness and job performance, voluntary turnover intention, organizational identification.

Finally, we suggest some ways to improve job performance and reduce voluntary turnover intention and improve organizational identification through results of these verification.

\section{CONCEPTUAL BACKGROUND}

\section{Organizational Citizenship Behavior}

Early, Katz and Kahn, in The Social Psychology of Organizations (1978), argued that effective organizations elicit three quite different patterns of behavior from members: (1) organizations must attract and hold people; (2) they must insure that members exhibit "dependable" levels of performance(in-role behavior); and (3) they must evoke "innovative and spontaneous behavior beyond role requirements for accomplishing organizational functions(extra-role behavior)." This last category includes cooperative activities with fellow members, actions protective of the system, self-training for additional contributions, and actions that promote a favorable climate for the organization in the external environment. In Organ \& Near(1983)'s research, prescribed third of three behavior type that is classified by Katz as "organizational citizenship behavior".

OCB is defined as extra-role behavior that is discretionary behavior, not directly related to the individual's job description and not recognized by the formal reward system, but behavior that helps the organization and/or its members. An example would be that, when a worker sees another worker in trouble or needing help, the worker goes to the other's 
aid without being asked or directed to help. The worker often leaves his own job to help but does not expect any material reward(Organ, 1988).

\begin{tabular}{l|l}
\multicolumn{1}{l}{ (1) Dimensions of OCB } & Dimensions \\
\hline \hline Researcher & altruism, generalized compliance \\
\hline Smith, Organ \& Near(1983) & consideration, self-acceptance, anti-sexism \\
\hline $\begin{array}{l}\text { Motowidlo(1984) } \\
\text { Konovsky(1986) }\end{array}$ & altruism, compliance, attendance \\
\hline Graham(1986) & rule obedience, enabling others, pursuit of excellence, loyalty, civic virtue \\
\hline Organ(1988) & altruism, conscientiousness, courtesy, civic virtue, sportsmanship \\
\hline Organ(1990) & altruism, conscientiousness, courtesy, civic virtue, sportsmanship, peacekeeping, cheerleading \\
\hline $\begin{array}{l}\text { MacKenzie, Podsakoff \& } \\
\text { Fetter(1991, 1993) }\end{array}$ & objective performance, altruism, courtesy, civic virtue, sportsmanship \\
\hline Williams \& Anderson(1991) & OCBI, OCBO \\
\hline $\begin{array}{l}\text { Van Dyne, Graham \& } \\
\text { Dienesch(1994) }\end{array}$ & $\begin{array}{l}\text { organizational obedience, organizational loyalty, organizational participation; social, } \\
\text { advocacy, functional }\end{array}$ \\
\hline Podsakoff, Ahearne \& MacKenzie(1997) & helping behavior, sportsmanship, civic virtue \\
\hline
\end{tabular}

This research examined laying emphasize on Organ's research which is verified by many researchers.

\section{Job Embeddedness}

For over 45 years, management scholars have theorized about and empirically investigated the causes of employees' voluntarily leaving jobs, or "voluntary employee turnover" (Maertz \& Campion, 1998). The concept of Job embeddedness extends theory and research on voluntary turnover.

Most of the current theory and research on voluntary turnover springs from the ideas of March and Simon (1958) on the perceived ease and desirability of leaving one's job. The perceived ease of movement is reflected by job alternatives, and the perceived desirability of movement is usually taken to mean job satisfaction. The traditional wisdom is that people become dissatisfied with their jobs, search for alternatives, compare those options with their current jobs using an expected-value-like decision process, and leave if any of the alternatives are judged to be better than their current situation(Mobley, 1977).

Although much of the research described above has shown significant results, the findings are modest, at best. In their quantitative reviews, Hom and Griffeth(1995) and Griffeth and colleagues(2000) reported that attitudinal variables control only about 4 to 5 percent of the variance in turnover.

That is why, a number of researchers have attempted to break away from the attitudes and alternatives model generally prescribed by the theorists mentioned above. The foundations for job embeddedness are three other sets of ideas that have emerged from this growing literature.

First, a body of empirical research suggests that many off-the-job factors are important for attachment. The original turnover models of Price and Mueller (1981), Steers and Mowday (1981), and Mobley (1982) include such "nonwork" influences as family attachments and conflicts between work and family roles. More recent research on "spillover" models explains how family and work life are related (Marshall, Chadwick, \& Marshall, 1992). Cohen (1995) shows how nonwork commitments like family, hobbies, and church influence job attitudes and attachment. Lee and 
Maurer (1999), moreover, found that haying children at home and a spouse were better predictors of leaving a job than organizational commitment.

Second, a variety of factors have been empirically associated with retention that are not attitudinal but organizational. Inducements to stay can derive from working with groups or on certain projects that create types of commitment other than the attraction a person has for his or her job or organization. For example, many companies use teams to induce attachments (Cohen \& Bailey, 1997). Reichers (1985) labeled these attachments "constituent commitments" and includes attachment to unions, teams, and other work-related groups.

Third, in research on the unfolding model of turnover (Lee \& Mitchell, 1994; Lee, Mitchell, Holtom, McDaniel, \& Hill, 1999), the cited authors describe different ways people decide to leave organizations, identifying four distinct paths. From our perspective, the interesting points are that many people who leave [1] are relatively satisfied with their jobs, (2) don't search for other jobs before leaving, and (3) leave because of some sort of precipitating event (which Lee and colleagues call a shock) rather than because of a negative attitude. In addition, the content or issues involved with shocks frequently occur off the job; a spouse relocating is an example.

Thus, these results provide clues as to why the attitude-search models only predict modestly well who leaves jobs. In many cases, negative attitudes or job search are simply not associated with leaving (Campion, 1991). Collectively, these different and nontraditional ideas helped Mitchell, Holtom, Lee, Sablyski, and Erez(2001) to develop the job emheddedness construct.

Mitchell, Holtom, Lee, Sablyski, and Erez(2001) focused on why people stay rather than on how they leave. In particular, they drew attention to the reasons people stay through their job embeddedness construct. Reflecting the idea of people's being "situated or connected in a social web," embeddedness has several key aspects: (1) the extent to which people have links to other people or activities, (2) the extent to which their jobs and communities fit other aspects in their "life spaces," and (3) the ease with which links could broken - what they would give up if they left their present settings. Mitchell and his coauthors called these three dimentions links, fit, and sacrifice, respectively, and they are important both on and off the job. Mitchell and his colleagues (2001) provided initial empirical support for job embeddedness. Briefly, job embeddedness includes individuals' (1) links to other people, teams, and groups, (2) perceptions of their fit with job, organization, and community, and (3) what they say they would have to sacrifice if they left their jobs.

Job embeddedness is conceived as a key mediating construct between specific on-the-job and off-the-job factors and employee retention. It represents a focus on the accumulated, generally nonaffective, reasons why an employee would not leave a job, which comprise a sort of stuckness, inertia, or bias toward the status quo. Each of the three dimensions -fit, links, and sacrifice-has an organizational and a community component. Though both "organization" and "community" are abstractions that are socially constructed, they capture domains in which people can be embedded. That is, job embeddedness can be disaggregated into two major components: on-the-job embeddedness (that is, organizational fit, links, and sacrifice) and off-the-job embeddedness (that is, community fit, links, and sacrifice).

Fit

Fit is defined as an employee's perceived compatibility or comfort with an organization and with his or her environment. An employee's personal values, career goals, and plans for the future must fit with the larger corporate culture and the demands of his or her immediate job (job knowledge, skills, and abilities). In addition, a person will consider how well he or she fits the community and surrounding environment. The better the fit, the higher the likelihood that an employee will feel professionally and personally tied to an organization(Mitchell, Holtom, Lee, Sablyski, and $\operatorname{Erez}(2001)$.

Links

Links are characterized as formal or informal connections between a person and institutions or other people. Embeddedness suggests that a numher of strands connect an employee and his or her family in a social, psychological, and 
financial web that includes work and nonwork friends, groups, and the community and the physical environment in which he or she lives. The higher the number of links between the person and the web, the more she or he is bound to job and organization. People have many links among the various aspects of their lives. Leaving their jobs and perhaps their homes can sever or require the rearrangement of some of these links.

\section{Sacrifice}

Sacrifice captures the perceived cost of material or psychological benefits that may be forfeited by leaving a job. For example, leaving an organization implies personal losses like giving up colleagues, interesting projects, or perks. The more an employee would give up when leaving, the more difficult it will be for him or her to sever employment with the organization (Shaw, Delery, Jenkins, \& Gupta, 1998). Community sacrifices (as well as links and fit to some extent) are mostly an issue if one has to relocate. Leaving a community that is attractive and safe and in which one is liked or respected can be hard.

\section{Voluntary Turnover Intention}

Voluntary turnover intention means that employees wish to leave at organization voluntarily as alternative variable of actual turnover. Turnover intention has been assumed and found to be the only antecedent having a direct effect on actual turnover (Coverdale \& Terborg, 1980; Fishbein \& Ajzen, 1974; Michaels \& Spector, 1982; Miller, Katerberg, \& Hulin, 1979; Mobley, 1977; Mobley, Homer, \& Hollingsworth, 1978; Mowday, Koberg, \& McArthur, 1984). after reviewing the literature on employee turnover processes, Mobley, Griffeth, Hand, and Meglino(1979) concluded that "behavioral intentions to stay or leave are consistently related to turnover behavior". Indeed, turnover intention has consistently been demonstrated to have a significant and positive relationship with turnover, with the average coefficient being $+.38($ Carsten \& Spector, 1987).

\section{Organizational Identification}

Organizational identification concerns the perception of "oneness" with an organization(Ashforth \& Mael, 1989). The construct has firm roots in social identity theory; Tajfel(1978) defined it as the "cognition of membership of a group and the value and emotional significance attached to this membership". The cognitive component of identification reflects the perceived amount of interests an individual and an organization share (Ashforth \& Mael, 1989). It conveys the extent to which an individual perceives him/herself as belonging to the group and as being a typical member of it. The affective component (feelings of pride in being part of the organization or feeling acknowledged in it) is important in the creation of a positive image of one's own organization, or achieving a "positive social identity" (Tajfel, 1982).

\section{HYPOTHESIS}

1. On-the-job embeddedness and organizational citizenship behavior

High on-the-job embeddedness reflects (1) many links, (2) a good fit, and/or (3)consequential things that an employee gives up by quitting, the motivation to perform should be high. That is, employees with high on-the-job embeddedness will (1) be involved in and tied to projects and people, (2) feel they fit well in their jobs and can apply their skills, and (3) sacrifice valued things if they quit. Correspondingly, the motivation to perform should be high. (Low motivation should occur when on-the-job embeddedness is low.)

The relationship between job embeddedness and the decision to perform can be further specified. In the last decade, the domain of performance has been divided into in-role and extra-role (e.g., Williams \& Anderson, 1991). In-role performance is similar to job-description-based specifications of performance, whereas organizational citizenship behavior is part of a larger family of extra-role behaviors (Van Dyne, Cummings, \& McLean Parks, 1995). Most often, citizenship is seen as an employee's actions that help others better perform their jobs (for instance, training co-workers) and thereby enhance organizational effectiveness. 
Conceptually, the more an individual is job embedded (or socially enmeshed) in an organization, the more likely he or she should be to display citizenship behaviors. In particular, people may be interdependent (or linked to one another), and helpful acts may be consistent with their feelings of comfort (or fit) stemming from being part of that social network. The more an employee fits a job, colleagues, and organization, the more natural it should be to perform citizenship behaviors. In addition, helping others may be perceived as promoting others' future helpful acts. Foregoing the opportunity to help other interdependent people may well be seen as a sacrificed opportunity to gain an owed favor. Indeed, the theory and research on social exchange (Van Dyne \& Ang, 1998), norms of reciprocity (Gouldner, 1960), perceived organizational support (Rhoades \& Eisenberger, 2002), and work status congruence (Holtom, Lee, \& Tidd, 2002) suggest that people come to feel obligated and want to help persons and organizations that have helped them.

Much of the above reasoning explicitly involves the effect of on-the-job embeddedness on (in-role) job performance and (extra-role) organizational citizenship. Most importantly, the attributes of a job and an organization should be significantly more salient for the immediate motivation (and decision) to perform than are off-the-job factors. On-the job embeddedness should be more proximal to a decision to perform (as manifested by citizenship behaviors and job performance) than the more distal decision to participate (as reflected by turnover and absences, which involve future states and off-thejob considerations). That is, employees have to perform immediately (or right now), whereas they may be absent next week or quit next month. Although off-the-job embeddedness should have an effect on performance, it should be relatively minor. In particular, the saliency of the immediate job and organization supersedes, renders less meaningful, or makes less potent the more distal effects of off-the job embeddedness on the decision to perform.

This study focus on individuals staying on their job. Therefore, because these contents and purpose of this research and a specificity of our country(Unlike United States of America, link with local community such as local community contribution activity is slight level yet), we measured only on-the-job embeddedness.

Hypothesis 1: On-the-job embeddedness will be positively related to organizational citizenship behavior. Hypothesis 1a: Individual's fit to the organization will be positively related to organizational citizenship behavior. Hypothesis 1b: Organizational links will be positively related to organizational citizenship behavior. Hypothesis 1c: Organizational-related sacrifice will be positively related to organizational citizenship behavior.

2. Organizational citizenship behavior and Organizational Identification, Job Performance, Voluntary Turnover Intention

\section{OCB and Job Performance}

Despite the widespread interest in the topic of organizational citizenship behaviors(OCBs), little empirical research has tested the fundamental assumption that these forms of behavior improve the effectiveness of work groups or organizations in which they are exhibited. Podsakoff, Michael, MacKenzie(1997) is tested the effects of OCBs on the quantity and quality of the performance of 218 people working in 40 machine crews in a paper mill located in the Northeastern United States were examined. The results indicate that helping behavior had a significant impact on performance quality. However, civic virtue had no effect on either performance measure.

\section{OCB and Voluntary Turnover Intention}

The relationship between OCB and turnover has not been well documented empirically. Although Rosse and Hulin (1985) included a group of avoidance behaviors (some of them appeared to be similar to OCBs) in their study, they conceptualized these behaviors only as reactions to job dissatisfaction and thus did not examine their impact on turnover. Indirect evidence is found in a study by Wells and Muchinsky (1985), in which they found that supervisors rated employees who quit their organizations as less reliable and less dependable than those who were promoted. Although Wells and Muchinsky did not define the concepts of reliability and dependability, they appear to be more like extrarole than in-role characteristics. In fact, this concept is similar to one type of OCB-conscientiousness. 
Also, Xiao-Ping Chen et al. (1998) conceptualized levels of organizational citizenship behavior (OCB) performance as a behavioral predictor of employee turnover and empirically examined the strength of this relationship. Data were collected from 205 supervisor-subordinate dyads across 11 companies in the People's Republic of China. The results provided considerable support for the hypothesis that supervisor-rated OCB was a predictor of subordinates' actual turnover. In particular, subordinates who were rated as exhibiting low levels of OCB were found to be more likely to leave an organization than those who were rated as exhibiting high levels of OCB.

OCB and Organizational Identification

Lee (1998) proposed that loyalty, participation, altruism of OCB had positive effects on Organizational Identification.

On the basis of the theoretical linkage and suggestive empirical relationship between OCB and staying in organization, we hypothesized that OCB is a predictor of job performance and voluntary turnover and organizational identification.

Hypothesis 2: $\quad$ Organizational citizenship behavior(altruism, conscientiousness, courtesy, civic virtue, sportsmanship) will be positively related to job performance, voluntary turnover intention, organizational identification.

Hypothesis 2a: Organizational citizenship behavior will be positively related to job performance.

Hypothesis 2b: Organizational citizenship behavior will be negatively related to voluntary turnover intention.

Hypothesis 2c: Organizational citizenship behavior will be positively related to organizational identification.

3. The Mediating effect of organizational citizenship behavior between on-the-job embeddedness and job performance, voluntary turnover, organizational identification

Lee, Mitchell, Sablynski, Burton \& Holtom(2004) extended research on Mitchell et al.(2001). Also, there are improved to understanding of the decision to participate and to perform at work. First, job embeddedness can be disaggregated into two major components: on-the-job embeddedness (that is, organizational fit, links, and sacrifice) and off-the-job embeddedness (that is, community fit, links, and sacrifice). Second, these two components may have different effects on indicators of performance and participation (absences and turnover). Third, emoyee withdrawal occurs over time, with a decision about participating. That is, on-the-job embeddedness significantly effects on OCB that is a predictor voluntary turnover. Moreover, we can analogize that this organization citizenship behavior will be influence to the performance, turnover, identification of organization for long-term.

On the basis of the reviewed theories, we also hypothesized that OCB mediate the effect of on-the-job embeddedness on organizational effectiveness.

Hypothesis 3: Organizational citizenship behavior mediate the effect of on-the-job embeddedness on job performance, voluntary turnover, organizational identification.

Hypothesis 3a: Organizational citizenship behavior mediate the positive effect of Individual's fit to the organization on job performance.

Hypothesis 3b: Organizational citizenship behavior mediate the negative effect of Individual's fit to the organization on voluntary turnover intention.

Hypothesis 3c: Organizational citizenship behavior mediate the positive effect of Individual's fit to the organization on organizational identification.

Hypothesis 3d: Organizational citizenship behavior mediate the positive effect of organizational links on job performance.

Hypothesis 3e: Organizational citizenship behavior mediate the negative effect of organizational links on voluntary turnover intention.

Hypothesis 3f: Organizational citizenship behavior mediate the positive effect of organizational links on organizational identification. 
Hypothesis 3g: Organizational citizenship behavior mediate the positive effect of organizational-related sacrifice on job performance.

Hypothesis 3h:. Organizational citizenship behavior mediate the negative effect of organizational-related sacrifice on voluntary turnover intention.

Hypothesis 3i: Organizational citizenship behavior mediate the positive effect of organizational-related sacrifice on organizational identification.

\section{DATA AND METHODS}

\section{Sample}

Surveys were distributed to 300 randomly selected employees in Seoul, Busan, and Gyeongnam, Korea Of the 300 surveys, 268 surveys (89.33\%) were returned. Thirteen surveys were not included in the analyses because they: (1) were illegible, (2) had no identifying information, or (3) were identifiable but blank. Thus, our sample's data come from 255 employees and represent a 85 percent response rate. Within our sample, Men Comprised 71.8 percent of the respondents; and 33.7 percent were about 20, 48.6 percent were in thirties; and 85.4 percent had taken more than some college courses; 45.9 percent work in the office; 49 percent were non-supervisors.

\section{Measure}

Fifty-two completed questionnaires were considered valid for the purpose.

$$
\text { On-the-job embeddedness }
$$

We assessed on-the-job embeddedness using 18 items from the scale described by Mitchell et al(2001) and Lee et al(2004). Five-point Likert scales were used. Response options were 1("never") to 5("always"), and a sample item is "I would sacrifice a lot if I left this job.”

\section{Organizational citizenship behavior}

To measure employees' OCB, we used 17 items developed by Niehoff \& Moorman(1993). We used the fivedimension scale. Each of five constructs-altruism, courtesy, sportsmanship, conscientiousness, and civic virtue included items describing specific behaviors. Response options were 1("strongly disagree") to 5 ("strongly agree"), and a sample item is "Helps others who have been absent."

Job Performance, Voluntary turnover intention, Organizational identification

Job Performance was measured with 4 items from Tsui(1984) and McAllister(1995). Response options were 1 (“strongly disagree") to 5 ("strongly agree").

Voluntary turnover intention was measured with 6 items from Mobely(1982) and Becker(1992). Response options were 1("strongly disagree") to 5 ("strongly agree"), and a sample item is "I often think about quitting."

Organizational identification was measured with 5 items from Mael \& Ashforth(1992). Response options were 1("strongly disagree") to 5("strongly agree"), and a sample item is "I become irritated when I hear others outside [organization] criticize the company."

\section{RESULTS}

To ensure that completed questionnaires conformed with reliability requirements, futher tests were conducted. An exploratory factor analysis with varimax rotation was conducted on all self-reported items for on-the-job embeddedness, organizational citizenship behavior, job performance, voluntary turnover intention, and organizational 
identification. Tests indicated that the factor loading of all variables exceed 0.5. Only, principle component analysis of "links" scale resulted in two unambiguous factors: a three-item factor comprised item referring to "individual's links" and three-items descriptive of "interpersonal links". The Cronbach's $\alpha$ reliability(using all the items) for this overall measure was $0.6604-0.9107$.

Table 1 presents correlations for all study variables.

Table 1

Correlations among Study Variables

\begin{tabular}{|c|c|c|c|c|c|c|c|c|c|c|c|c|c|c|c|}
\hline & 1 & 2 & 3 & 4 & 5 & $\theta$ & 7 & 8 & 9 & 10 & 11 & 12 & 13 & 14 & 15 \\
\hline 1. age & 1.000 & & & & & & & & & & & & & & \\
\hline 2. Education & 0.038 & 1000 & & & & & & & & & & & & & \\
\hline 3. position & $0.615^{+4}$ & $0.160^{\circ}$ & 1.000 & & & & & & & & & & & & \\
\hline 4. fit & 0.118 & 0.093 & $0.233^{\mu+}$ & 1.000 & & & & & & & & & & & \\
\hline 5. interpersonal links & $0.130^{\circ}$ & $0.129^{+}$ & $0.203^{4+}$ & $0.219^{+4+}$ & 1000 & & & & & & & & & & \\
\hline 6. individual's links & $0.683^{+4}$ & -0.028 & $0.674^{4+}$ & $0.213^{++4}$ & $0.199^{+4}$ & 1000 & & & & & & & & & \\
\hline 7. sacrifice & 0.070 & 0.073 & $0.178^{\mu+}$ & $0.671^{1++}$ & $0.137^{t}$ & $0.170^{*}$ & 1.000 & & & & & & & & \\
\hline 8. altruism & $0.233^{+4}$ & 0.074 & $0.300^{\mathrm{Nt}}$ & $0.528^{2+1}$ & $0.173^{4+}$ & $0.317^{\mu+}$ & $0.445^{+1+}$ & 1.000 & & & & & & & \\
\hline 9. conscientiousness & $0.156^{+}$ & $0.155^{4}$ & $0.230^{4+}$ & $0.366^{+4}$ & $0.148^{*}$ & $0.214^{4+4}$ & $0.366^{+4+}$ & $0.285^{+4}$ & 1000 & & & & & & \\
\hline 10. courtesy & -0.12 & $0.196^{4}$ & $0.142^{+}$ & $0.533^{++4}$ & $0.138^{+}$ & 0.090 & $0.440^{+1+}$ & $0.464^{4++}$ & $0.379^{+4+}$ & 1000 & & & & & \\
\hline 11. civic virtue & $0.260^{+4}$ & 0.072 & $0.277^{4+}$ & $0.627^{\prime+4}$ & $0.141^{+}$ & $0.2500^{4+}$ & $0.565^{4+}$ & $0.45^{+4}$ & $0.432^{4++}$ & $0.465^{4+}$ & 1.000 & & & & \\
\hline 12. sportsmanship & $0.615^{+4}$ & 0.065 & $0.135^{+}$ & $0.370^{\text {t+ }}$ & $0.146^{4}$ & 0.110 & $0.257^{+4 t}$ & $0.253^{+4}$ & $0.200^{+4+}$ & $0328^{+4}$ & $0.291^{+*}$ & 1.000 & & & \\
\hline 13. Job performance & 0.094 & 0.085 & $0.202^{4+}$ & $0.513^{++4}$ & 0.115 & $0.165^{4+}$ & $0.410^{\mathrm{H+}}$ & $0.486^{++1}$ & $0.378^{4++}$ & $0.582^{\mu+}$ & $0.515^{4+}$ & $0.388^{+*}$ & 1000 & & \\
\hline $\begin{array}{l}\text { 14. voluntary tumover } \\
\text { intention }\end{array}$ & $-0.142^{4}$ & -0.092 & $-0.192^{*}$ & $-0.680^{*+}$ & $-0.188^{*}$ & $-0.175^{4}$ & $-0.686^{\mu+}$ & $-0.432^{++}$ & $-0.336^{4+}$ & $-0.480^{n+1}$ & $-0.495^{+\omega}$ & $-0.497^{+*}$ & $-0.433^{+4}$ & 1000 & \\
\hline $\begin{array}{l}\text { 15. organizational } \\
\text { identification }\end{array}$ & $0.203^{++1}$ & $0.150^{\circ}$ & $0.299^{4++}$ & $0.636^{.+4}$ & $0.207^{74}$ & $0.236^{4+}$ & $0.566^{4+}$ & $0.555^{++4}$ & $0.328^{++4}$ & $0.514^{4+t}$ & $0.596^{+4+}$ & $0.285^{+*}$ & $0.533^{++}$ & $0.636^{+4+}$ & 1.000 \\
\hline
\end{tabular}

Next, we used multiple-regression analysis to test each of our hypotheses. Tolerance and Variance Inflation Factor(VIF) values were examined. Tolerance values above .10 and VIF values below 10 indicating that multicollinearity was not a problem in these data.

\section{(1) Hypothesis 1}

Hypothesis 1 predicted that on-the-job embeddedness would be positively related with OCB. And, Hypothesis 1a predicted. individual's fit to the organization would be positively related with OCB. Hypothesis $1 \mathrm{~b}$ predicted, organizational links would be positively related with OCB. Hypothesis 1c predicted, organizational-related sacrifice would be positively related with OCB. As expected, individual's fit to the organization $(\beta=0.530, p=0.000)$ and organizationalrelated sacrifice $(\beta=0.214, p=0.000)$ was positively related to OCB. But, interpersonal's links was not predictive of $\operatorname{OCB}(\mathrm{p}=0.321)$ and individual's links was predictive $\operatorname{OCB}(\beta=0.125, \mathrm{p}=0.005)$. Thus, Hypothesis $1 \mathrm{a}, 1 \mathrm{c}$ is supported, and Hypothesis $1 \mathrm{~b}$ is only partially supported. Therefore, Hypothesis 1 is partially supported. 
Table 2

Results of Regression Analyses Predicting OCB

\begin{tabular}{|c|c|c|c|c|c|c|}
\hline \multirow{2}{*}{\multicolumn{2}{|c|}{$\begin{array}{l}\text { independent } \\
\text { variables }\end{array}$}} & $\begin{array}{l}\text { standardized } \\
\text { coefficient }\end{array}$ & \multirow[t]{2}{*}{$\mathrm{t}$} & \multirow[t]{2}{*}{$\mathrm{P}$-value } & \multirow[t]{2}{*}{ F-value } & \multirow[t]{2}{*}{ Partial $\mathrm{H}^{2}$} \\
\hline & & $\beta$ & & & & \\
\hline & fit & 0.530 & 9.008 & $0.000^{*+*}$ & 242863 & 0.490 \\
\hline 2 & sacrifice & 0.214 & 3.670 & $0,000^{*++}$ & 134550 & 0,026 \\
\hline 3 & $\begin{array}{l}\text { individual's } \\
\text { links }\end{array}$ & 0.125 & 2,819 & $0,005^{* *}$ & 94824 & 0,015 \\
\hline & Model & \multicolumn{5}{|c|}{$\begin{array}{l}\mathrm{H}^{2}=0.531 \quad \text { Adjusted } \mathrm{H}^{2}=0,526 \\
\mathrm{~F} \text {-value }=94,824 \mathrm{P} \text {-value (to } \mathrm{F} \text {-value) }=0,000\end{array}$} \\
\hline
\end{tabular}

${ }^{x x} \mathrm{p}<0,001, \quad{ }^{x x}<<0,01, \quad x<0,05$

(2)

\section{Hypothesis 2}

Hypothesis 2 predicted OCB(altruism, conscientiousness, courtesy, civic virtue, sportsmanship) would be positively related with staying in organization. And, Hypothesis 2 a predicted OCB would be positively related with job performance. As results, OCB's altruism $(\beta=0.180, \mathrm{p}=0.001)$, sportsmanship $(\beta=0.166, \mathrm{p}=0.001)$, civic virtue $(\beta=0.223$, $\mathrm{p}=0.000)$, $\operatorname{courtesy}(\beta=0.340, \mathrm{p}=0.000)$ was positively related to job performance. But, conscientiousness was not predictive of job performance $(\mathrm{p}=0.191)$. Thus, Hypothesis $2 \mathrm{a}$ is only partially supported.

Hypothesis $2 \mathrm{~b}$ predicted OCB would be negatively related with voluntary turnover intention. As results, OCB's altruism $(\beta=-0.145, p=0.012)$, courtesy $(\beta=-0.194, p=0.001)$, civic virtue $(\beta=-0.241, p=0.000)$, sportsmanship $(\beta=-0.327$, $\mathrm{p}=0.000$ ) was negatively related to voluntary turnover intention. But, conscientiousness was not predictive of voluntary turnover intention $(\mathrm{p}=0.210)$. Thus, Hypothesis $2 \mathrm{~b}$ is only partially supported.

Hypothesis $2 \mathrm{c}$ predicted OCB would be positively related with organizational identification. As results, OCB's altruism $(\beta=0.285, \mathrm{p}=0.000)$, courtesy $(\beta=0.214, \mathrm{p}=0.000)$, civic virtue $(\beta=0.361, \mathrm{p}=0.000)$ was positively related to organizational identification.. But, conscientiousness $(\mathrm{p}=0.830)$, sportsmanship $(\mathrm{p}=0.377)$ was not predictive of organizational identification. Thus, Hypothesis $2 \mathrm{c}$ is only partially supported. Also, Hypothesis 2 is only partially supported.

\section{Table 3}

Results of Regression Analyses Predicting Job performance

\begin{tabular}{|c|c|c|c|c|c|c|}
\hline \multirow{2}{*}{\multicolumn{2}{|c|}{$\begin{array}{l}\text { independent } \\
\text { variables }\end{array}$}} & $\begin{array}{c}\text { standardized } \\
\text { coefficient }\end{array}$ & \multirow[t]{2}{*}{$\mathrm{t}$} & \multirow[t]{2}{*}{$\mathrm{P}$-value } & \multirow[t]{2}{*}{$\mathrm{F}$-value } & \multirow[t]{2}{*}{ Partial $\mathrm{R}^{2}$} \\
\hline & & B & & & & \\
\hline 1 & courtesy & 0.340 & 6.063 & $0.000^{* * * * *}$ & 129.483 & 0.339 \\
\hline 2 & civic virtue & 0.223 & 3.986 & $0.000^{* * * *}$ & 89.262 & 0.076 \\
\hline 3 & sportsmanship & 0.166 & 3.326 & $0.001^{* * * *}$ & 66.252 & 0.027 \\
\hline 4 & altruism & 0.180 & 3.250 & $0,001^{\text {***** }}$ & 54,221 & 0.023 \\
\hline & Mode1 & $\begin{array}{l}\mathrm{R}^{2}=0.465 \\
\mathrm{~F} \text {-value }=54.221\end{array}$ & $\begin{array}{l}\text { Adjust } \\
\text { P-valu }\end{array}$ & $\begin{array}{l}\text { ted } R^{2}=0 \text {. } \\
\text { ue (to } F \text { - }\end{array}$ & $\begin{array}{l}56 \\
\text { alue })=0.00\end{array}$ & \\
\hline
\end{tabular}


Table 4

Results of Regression Analyses Predicting Voluntary turnover intention

\begin{tabular}{|c|c|c|c|c|c|c|}
\hline \multirow{2}{*}{\multicolumn{2}{|c|}{ independent variables }} & $\begin{array}{l}\text { standardized } \\
\text { coefficient }\end{array}$ & \multirow[t]{2}{*}{$\mathrm{t}$} & \multirow[t]{2}{*}{ P-value } & \multirow[t]{2}{*}{ F-value } & \multirow[t]{2}{*}{ Partial $\mathrm{F}^{2}$} \\
\hline & & $\beta$ & & & & \\
\hline 1 & sportsmanship & $-0,327$ & $-6,398$ & $0.000^{n+n+1}$ & 82,970 & 0.247 \\
\hline 2 & civic virtue & -0.241 & -4212 & $0,000^{n+*+}$ & 77.650 & 0.134 \\
\hline 3 & courtesy & -0.194 & -3.368 & $0.001^{n+n+1}$ & 61.279 & 0.041 \\
\hline 4 & altruism & -0.145 & -2545 & $0.012^{*}$ & 48.580 & 0.015 \\
\hline & Model & $\begin{array}{l}\mathrm{A}^{2}=0.437 \\
\mathrm{~F}-\text { value }=48.580\end{array}$ & $\begin{array}{l}\text { Adjusted } \\
\text { P-value }\end{array}$ & $\begin{array}{l}\mathrm{A}^{2}=0.4 \\
\text { to } \mathrm{F}-\mathrm{y}\end{array}$ & $=0.000$ & \\
\hline
\end{tabular}

${ }^{x x z} \mathrm{p}<0,001,{ }^{x x}<<0,01,{ }^{x} \mathrm{p}<0,05$

Table 5

Results of Regression Analyses Predicting Organizational identification

\begin{tabular}{|c|c|c|c|c|c|c|}
\hline \multicolumn{2}{|c|}{$\begin{array}{c}\text { independent } \\
\text { variables }\end{array}$} & $\begin{array}{c}\text { standardized } \\
\text { cœefficient }\end{array}$ & $\mathrm{t}$ & P-value & F-value & Partial $\mathrm{A}^{2}$ \\
\hline 1 & $\begin{array}{l}\text { civic } \\
\text { virtue }\end{array}$ & 0.361 & 6.647 & $0,000^{n+*}$ & 139.223 & $0.355 ;$ \\
\hline 2 & altruism & 0.285 & 5.246 & $0,000^{*+*}$ & 103.407 & 0.096 \\
\hline 3 & courtesy & 0.214 & 3965 & $0.000^{*+*+1}$ & 78.207 & 0.032 \\
\hline & Model & $\begin{array}{l}\mathrm{H}^{2}=0.483 \\
\mathrm{~F}-\text { value }=78.20 ?\end{array}$ & $\begin{array}{l}\text { sted } \\
\text { lue }\end{array}$ & $\begin{array}{l}=0.477 \\
\text { F-valu }\end{array}$ & & \\
\hline
\end{tabular}

${ }^{x x} \mathrm{p}<0,001,{ }^{x x} \mathrm{p}<0,01, \quad \mathrm{p}<0,05$

To test for mediation, one should estimate the three following regression equations: first, regressing the mediator on the independent variable; second, regressing the dependent variable on the independent variable; and third, regressing the dependent variable on both the independent variable and on the mediator. Separate coefficients for each equation should be estimated and tested. There is no need for hierarchical or stepwise regression or the computation of any partial or semipartial correlations. These three regression equations provide the tests of the linkages of the mediational model.

Table 6 shows that OCB mediate the positive effect of on-the-job embeddedness on job performance, and Table 7 shows that OCB mediate the negative effect of on-the-job embeddedness on voluntary turnover intention, and Table 8 shows that OCB mediate the positive effect of on-the-job embeddedness on organizational identification.

As examined Table 6, 7 and 8, Hypothesis 3(3a, 3b, 3c. 3d, 3e, 3f, 3g, 3h, 3i) is supported. 
Table 6

Mediating effects of OCB between on-the-job embeddedness and Job Performance

\begin{tabular}{|c|c|c|c|c|c|}
\hline $\begin{array}{c}\text { independent } \\
\text { variables }\end{array}$ & & step & \multicolumn{2}{|c|}{$\begin{array}{c}\text { dependent } \\
\text { variables }\end{array}$} & mediating effect \\
\hline \multirow{6}{*}{ fit } & & 1 & $0.700^{* * k+}$ & $\mathrm{O}$ & \multirow{6}{*}{ perfect mediation } \\
\hline & & 2 & $0.513^{* * k+k}$ & 0 & \\
\hline & 3 & independent & 0.080 & $\mathrm{X}$ & \\
\hline & 4 & mediator & $0.619^{* \text { *kt }}$ & 0 & \\
\hline & \multicolumn{2}{|c|}{ Adjusted $R^{2}$} & \multicolumn{2}{|c|}{0.454} & \\
\hline & & $F$ & \multicolumn{2}{|c|}{106.486} & \\
\hline \multirow{6}{*}{$\begin{array}{l}\text { individual's } \\
\text { links }\end{array}$} & & 1 & $0.274^{* * k}$ & 0 & \multirow{6}{*}{ perfect mediation } \\
\hline & & 2 & $0.165^{* *}$ & 0 & \\
\hline & 3 & independent & -0.022 & $\mathrm{X}$ & \\
\hline & 4 & mediator & $0.680^{* k \mathrm{kk}}$ & 0 & \\
\hline & \multicolumn{2}{|c|}{ Adjusted $R^{2}$} & \multicolumn{2}{|c|}{0.451} & \\
\hline & & $F$ & \multicolumn{2}{|c|}{105.294} & \\
\hline \multirow{6}{*}{ sacrifice } & & 1 & $0.591^{\text {*ak }}$ & O & \multirow{6}{*}{ perfect mediation } \\
\hline & & 2 & $0.410^{\text {*kok }}$ & O & \\
\hline & 3 & independent & 0.018 & $\mathrm{X}$ & \\
\hline & 4 & mediator & $0.664^{* * k}$ & $\mathrm{O}$ & \\
\hline & & djusted $R^{2}$ & \multicolumn{2}{|c|}{0.451} & \\
\hline & & $\mathrm{F}$ & \multicolumn{2}{|c|}{105.197} & \\
\hline
\end{tabular}

$7+n<0,001, " p<0,01$

Table 7

Mediating effects of OCB between on-the-job embeddedness and voluntary turnover intention

\begin{tabular}{|c|c|c|c|c|c|}
\hline independent & \multirow{2}{*}{\multicolumn{2}{|c|}{$\begin{array}{c}\text { step } \\
1 \\
\end{array}$}} & \multicolumn{2}{|c|}{ dependent variables } & mediating effect \\
\hline \multirow{6}{*}{ fit } & & & $0.700^{17}$ & 0 & \multirow{6}{*}{ partial mediation } \\
\hline & & 2 & $-0.680^{17}$ & 0 & \\
\hline & 3 & independent & $-0.431^{\ldots+}$ & 0 & \\
\hline & 4 & mediator & $-0.356^{m+1}$ & 0 & \\
\hline & \multicolumn{2}{|c|}{ Adjusted $\mathrm{A}^{2}$} & \multicolumn{2}{|c|}{0.523} & \\
\hline & & $\mathrm{F}$ & \multicolumn{2}{|c|}{140.047} & \\
\hline \multirow{6}{*}{ individual's links } & & 1 & $0.274^{11+}$ & 0 & \multirow{6}{*}{ perfect mediation } \\
\hline & & 2 & $-0.175^{\prime \prime}$ & 0 & \\
\hline & 3 & independent & 0.006 & $\mathrm{X}$ & \\
\hline & 4 & mediator & $0.659^{\prime \prime}$ & 0 & \\
\hline & \multicolumn{2}{|c|}{ Adjusted $\mathrm{A}^{2}$} & \multicolumn{2}{|c|}{0.427} & \\
\hline & & $\mathrm{F}$ & \multicolumn{2}{|c|}{95.762} & \\
\hline \multirow{6}{*}{ sacrifice } & & 1 & $0.591^{\ldots+}$ & 0 & \multirow{6}{*}{ partial mediation } \\
\hline & & 2 & $-0.686^{m+1}$ & 0 & \\
\hline & 3 & independent & $-0.457^{\cdots+}$ & 0 & \\
\hline & 4 & mediator & $-0.387^{\ldots+}$ & 0 & \\
\hline & \multicolumn{2}{|c|}{ Adjusted $\mathrm{A}^{2}$} & \multicolumn{2}{|c|}{0.565} & \\
\hline & & F & \multicolumn{2}{|c|}{165.650} & \\
\hline
\end{tabular}

${ }^{x x} \mathrm{p}<0,001,{ }^{x x} \mathrm{p}<0,01,{ }^{x} \mathrm{p}<0,05$ 
Table 8

Mediating effects of OCB between on-the-job embeddedness and organizational identification

\begin{tabular}{|c|c|c|c|c|c|}
\hline $\begin{array}{c}\text { independent } \\
\text { variables }\end{array}$ & & step & \multicolumn{2}{|c|}{$\begin{array}{l}\text { dependent } \\
\text { variables }\end{array}$} & mediating effect \\
\hline \multirow{6}{*}{ fit } & & 1 & $0.700^{17}$ & 0 & \multirow{6}{*}{ partial mediation } \\
\hline & & 2 & $0.636^{1+1}$ & 0 & \\
\hline & 3 & independent & $0.353^{\ldots+1}$ & 0 & \\
\hline & 4 & mediator & $0.406^{1+1}$ & 0 & \\
\hline & \multicolumn{2}{|c|}{ Adjusted $\mathrm{H}^{2}$} & \multicolumn{2}{|c|}{0.485} & \\
\hline & & $\mathrm{F}$ & \multicolumn{2}{|c|}{120.606} & \\
\hline \multirow{6}{*}{$\begin{array}{l}\text { individual's } \\
\text { links }\end{array}$} & & 1 & $0.274^{1+11}$ & 0 & \multirow{6}{*}{ perfect mediation } \\
\hline & & 2 & $0.236^{m+1}$ & 0 & \\
\hline & 3 & independent & 0.062 & $\mathrm{X}$ & \\
\hline & 4 & mediator & $0.635^{\cdots 11}$ & 0 & \\
\hline & \multicolumn{2}{|c|}{ Adjusted $\mathrm{H}^{2}$} & \multicolumn{2}{|c|}{0.425} & \\
\hline & & $\mathrm{F}$ & \multicolumn{2}{|c|}{94.374} & \\
\hline \multirow{6}{*}{ sacrifice } & & 1 & $0.591^{\cdots+1}$ & 0 & \multirow{6}{*}{ partial mediation } \\
\hline & & 2 & $0.566^{1+1}$ & 0 & \\
\hline & 3 & independent & $0.278^{1+1}$ & 0 & \\
\hline & 4 & mediator & $0.488^{1+1+}$ & 0 & \\
\hline & \multicolumn{2}{|c|}{ Adjusted $\mathrm{R}^{2}$} & \multicolumn{2}{|c|}{0.472} & \\
\hline & & $\mathrm{F}$ & \multicolumn{2}{|c|}{114.440} & \\
\hline
\end{tabular}

${ }^{x x} \mathrm{p}<0,001,{ }^{x x} \mathrm{p}<0,01,{ }^{x} \mathrm{p}<0,05$

\section{DISCUSSION}

This study founded correlation of on-the-job embeddedness, job performance, voluntary turnover and organizational identification. Also, it is founded that the mediating effect of organizational citizenship behavior in that relationship. The findings have implications for organizations.

First, job embeddedness (which can be established through building community, developing a sense of belonging, establishing deep ties among employees, and deepening social capital) may increase retention, attendance, citizenship, and job performance. Furthermore, organizations can be proactive about job embeddedness: links can be increased through teams and long-term projects; sacrifice can be increased by connecting job and organizational rewards to longevity; and fit can be increased by matching employees' knowledge, skills, abilities, and attitudes with a job's requirements. Equally important, managers can increase off-the-job embeddedness by providing people with information about the community surrounding their workplace and by providing social support for local activities and events (Mitchell, Holtom, \& Lee, 2001).

Second, the present study provide support for our hypothesis that OCB mediate the negative effect of on-the-job embeddedness on voluntary turnover intention. And, OCB is negatively related to voluntary turnover intention. Our results clearly show that employees who exhibit low levels of OCB are more likely to leave an organization than those who exhibit high levels of OCB. Therefore, organizations must try that encourage for employees through OCB. Seniors' initiative is required for setting an example. Can plan together organization's development and employee's growth through these effort. 
However, this research has some limitations. On the basis of this, research direction that can be spread in hereafter is as following.

- $\quad$ First, concept of job embeddedness that is used as independent variable in this research is concept that include both on-the-job factors and off-the-job factors. However, because this research wishes to offer constructive suggestion in corporation, only we executed empirical test for on-the-job embeddedness. Did so because of special quality of our country, but, If interchange with local community is increased later, that study together offthe-job embeddedness may become significant research.

- Second, It is founded high relationship between turnover intention and really voluntary turnover in many researches, but it is having limit that cannot do that take place of actually voluntary turnover, necessarily. Therefore, to grasp correctly whether independent variable influences to turnover process, research that measure including actual voluntary turnover may have to be executed.

- $\quad$ Third, Although this research examined that job embeddedness effects on employee's job performance, voluntary turnover intention and organizational identification, it is true that psychological part, that variables of oganizational effectiveness that is used by this research can receive effect according to individual personality, is included. Thus, Future research can be examined mediation effect by individual personality in this relationship.

Finally, to problem of a measurement tool, this research used only questionnaire. But, if used method such as interview together, this research may explain more definitely reason with these results.

\section{REFERENCES}

1. Andersson, U. \& Forsgren, M., "In Search of Centre of Excellence: Network Embeddedness and Subsidiary Roles in Multinational Corporations," Management International Review, Vol. 40, No. 4, 2000, pp.329-350.

2. Augustine, J. C., Personnel Turnover in Handbook of Modern Personnel Administration, New York: McGrawHill, 1972.

3. Baron, R. M. \& Kenny D. A., "The Moderator-Mediator Variable Distinction in Social Psychological Research : Conceptual, Strategic, and Statistical Considerations," Journal of Personality and Social Psychology, Vol. 51, No. 6, 1986, pp.1173-1182.

4. Bateman, T. S. \& Organ, D. W., "Job Satisfaction and the Good Soldiers: The Relationship Between Affect and Employee "Citizenship"," Academy of Management Journal, Vol. 26, No. 4, 1983, pp.587-595.

5. Becker, T. E., "Foci and Bases of Commitment: Are They Distinctions Worth Making?," Academy of Management Journal, Vol. 35, No. 1, 1992, pp.232-244.

6. $\quad$ Blumberg, M. \& Pringle, C. D., "The Missing Opportunity in Organizational Research: Some Implications for a Theory of Work Performance," Academy of Management Review, Vol. 7, No. 4, 1982, pp.560-569.

7. Borman, W. C. \& Motowidlo, S. J., "Expending the Criterion Domain to Include Elements of Contextual Performance" In N. Schmitt, W. C. Berman \& Associates (Eds.), Personnel Selection in Organization, San Francisco, CA: Jossey, 1993

8. $\quad$ Bowlby, J., Attachment and Loss: Vol. 1. Attachment (2nd ed), New York: Basic Books, 1982.

9. Brief, A. P. \& Motowidlo, S. J., "Prosocial Organizational Behaviors," Academy of Management Review, Vol. 11, No. 4, 1986, pp.710-725.

10. Brown, M. E., "Identification and Some Conditions of Organizational Involvement," Administrative Science Quarterly, Vol. 14, No. 3, 1969, pp. 346-355.

11. Cappelli, P., "A Market-Driven Approach to Retaining Talent," Harvard Business Review, Vol. 78, No. 1, 2000, pp. 103-111.

12. Cascio, W. F., "Downsizing: What Do We Know? What Have We Learned?," Academy of Management Executive, Vol. 7, No. 1, 1993, pp.95-104.

13. Cohen, A., "An Examination of the Relationships Between Work Commitment and Nonwork Domains," Human Relations, Vol. 48, No. 3, 1995, pp.239-264.

14. Cohen, S. G. \& Bailey, D. E., "What Makes Teams Work: Group Effectiveness Research from the Shop Floor to the Executive Suite," Journal of Management, Vol. 23, No. 3, 1997, pp.239-290. 
15. Coleman, V. I. \& Borman, W. C., "Investigating the Underlying Structure of the Citizenship Performance Domain," Human Resource Management Review, Vol. 10, No. 1, 2000, pp.25-44.

16. Dicken, P., Forsgren, M. \& Malmberg, A., The Local Embeddedness of Transnational Corporations. In Globalization, Institutions and Regional Development in Europe, eds, Amit, A. and Thrift, N. pp.23-24, Oxford University Press, New York, 1994.

17. Etzioni, A., "Two Approaches to Organizational Analysis: A Critique and a Suggestion," Administrative Science Quarterly, Vol. 5, No. 2, 1960, pp.257-278.

18. George, J. M. \& Brief, A. P., "Feeling Good-Doing Good: A Conceptual Analysis of the Mood at WorkOrganizational Spontaneity Relationship," Psychological Bulletin, Vol. 112, No. 2, 1992, pp.310-329.

19. Grabher, G., Rediscovering the Social in the Economics of Interfirm Relations, In The Embedded Firm, On the Socioeconomics of Industrial Networks, ed. G. Grabher, pp.1-32, Routledge, London, 1993.

20. Graham, J. W., "Principled Organizational Dissent: A Theoretical Essay,"Research in Organizational Behavior, Vol. 8, 1986, pp.1-52.

21. ., "An Essay on Organizational Citizenship Behavior," Employee Responsibilities and Rights Journal, Vol, 4, 1991, pp. 249-270.

22. Griffeth, R. W., Hom, P. W. \& Gaertner, S., "A Meta-Analysis of Antecedents and Correlates of Employee Turnover: Update, Moderator Tests, and Research Implications for the Next Millennium," Journal of Management, Vol. 26, No. 3, 2000, pp.463-488.

23. Hackman, J. R. \& Oldham, G. R., Work Redesign, Addison-Wesley Publishing Company, 1980.

24. Hall, D. T., Schneider, B. \& Nygren, H. T., "Personal Factors in Organizational Identification," Administrative Science Quarterly, Vol. 15, No. 2, 1970, pp.176-190.

25. Hom, P. W. \& Griffeth, R. W., "Structural Equations Modeling Test of a Turnover Theory: Cross-Sectional and Longitudinal Analyses," Journal of Applied Psychology, Vol. 76, No. 3, 1991, pp.350-366.

26. Caranikas-Walker, F., Prussia, G. E. \& Griffeth, R. W., "A Meta-Analytical Structural Equations Analysis of a Model of Employee Turnover." Journal of Applied Psychology, Vol. 77, No. 6, 1992, pp.890-909. , \& Griffeth, R. W., Employee Turnover, Cincinnati: South-Western, 1995.

27. Hulin, C. L., Roznowski, M. \& Hachiya, D., "Alternative Opportunities and Withdrawal Decisions: Empirical and Theoretical Discrepancies and an Integration”, Psychological Bulletin, Vol. 97, No. 2, 1985, pp. 233-250. , Adaption, persistence and commitment in organizations. In M. D. Dunnette \& L. M. Hough (Eds.), Handbook of industrial and organizational psychology(2nd ed.): 445-507. Palo Alto, CA: Consulting Psychologists Press, 1991.

30. Karambayya, R., "Contextual Predictors of Organizational Citizenship Behavior," Academy of Management Proceedings, 1990, pp.221-225.

31. Katz, D., "The Motivational Basis of Organizational Behavior," Behavioral Science, Vol. 9, 1964, pp.131-146.

32. _ \& Kahn, R. L., The Social Psychology of Organizations, 2nd ed., New York: John Wiley \& Sons, Inc., 1978.

33. Lee, T. W. \& Maurer, S. D., "The Effects of Family Structure on Organizational Commitment, Intention to Leave and Voluntary Turnover," Journal of Managerial Issues, Vol. 11, No. 4, 1999, pp.493-513.

34. _ Mitchell, T. R., "An Alternative Approach: The Unfolding Model of Voluntary Employee Turnover," Academy of Management Review, Vol. 19, No. 1, 1994, pp.51-89.

35. — Mitchell, T. R., Holtom. B. C., McDaniel, L. S. \& Hill, J. W., "The Unfolding Model of Voluntary Turnover: A Replication and Extension," Academy of Management Journal, Vol. 42, No. 4, 1999, pp.450-462.

36. — Mitchell, T. R., Sablynski, C. J., Burton, J. P. \& Holtom, B. C., "The Effects of Job Embeddedness on Organizational Citizenship, Job Performance, Volitional Absences, and Voluntary Turnover," Academy of Management Journal, Vol. 47, No. 5, 2004, pp.711-722.

37. MacKenzie, S. B., Podsakoff, P. M. \& Fetter. R., "Organizational Citizenship Behavior and Objective Productivity as Determinants of Managerial Evaluations of Salespersons' Performance," Organizational Behavior and Human Decision Processes, Vol. 50, No. 1, 1991, pp.123-150.

38. \& _ _ "The Impact of Organizational Citizenship Behavior on Evaluations of Salesperson Performance," Journal of Marketing, Vol. 57, No. 1, 1993, pp.70-80.

39. Mael, F. Organizational Identification: Construct Redefinition and a field application with organizational alumni, Unpublished doctoral dissertation, Wayne State University, Detroit, 1988. 
40. _ _ _ _ Ashforth, B. E., "Alumni and Their Alma Mater: A Partial Test of The Reformulated Model of Organizational Identification, Journal of Organizational Behavior, Vol. 13, No. 2, 1992, pp.103-123.

41. Maertz, C. P. \& Campion, M. A., "25 years of voluntary turnover research: A review and critique," International Review of Industrial and Organizational Psychology, Vol. 13, 1998, pp.49-81.

42. March, J. G. \& Simon, H. A., Organizations, New York: Wiley, 1958.

43. Marshall, C. M., Chadwick, B. A. \& Marshall, B. C., "The Influence of Employment on Family Interaction, Well-Being, and Happiness," in S. J. Bahr(Ed.,), Family Research: A Sixty-Year Review 1930-1990, Vol. 2, 1992, pp.167-229.

44. McAllister, D. J., "Affect-And Cognition-Based Trust as Foundations for Interpersonal Cooperation in Organizations," Academy of Management Journal, Vol. 38, No. 1, 1995, pp.24-59.

45. Meyer, J. P. \& Allen, N. J.,"Testing the "Side-Bet Theory" of Organizational Commitment: Some Methodological Considerations," Journal of Applied Psychology, Vol. 69, No. 3, 1984, pp.372-378.

46. Mitchell, T. R., Holtom, B. C., Lee, T. W., Sablynski, C. J. \& Erez, M., "Why People Stay: Using Job Embeddedness to Predict Voluntary Turnover," Academy of Management Journal, Vol. 44, No. 6, 2001, pp.1102-1121.

47. Mobley, W. H., "Intermediate Linkages in the Relationship Between Job Satisfaction and Employee Turnover," Journal of Applied Psychology, Vol. 62, No. 2, 1977, pp.237-240.

48. _ Horner, S. O. \& Hollingsworth, A. T., "An Evaluation of Precursors of Hospital Employee Turnover," Journal of Applied Psychology, Vol. 63, No. 4, 1978, pp.408-414.

49.
50. Employee turnover: Causes, Consequences, and Control, Reading, Mass.:Addison-Wesley, 1982. Management Journal, Vol. 27, No. 4, 1984, pp.910-915.

51. _ _ _ _ Some Basic Issues Related to Contextual Performance and Organizational Citizenship Behavior in Human Resource Management," Human Resource Management Review, Vol. 10, No. 1, 2000, pp.115-126.

52. Niehoff, B. P. \& Moorman, R. H., "Justice As a Mediator of the Relationship Between Methods of Monitoring and Organizational Citizenship Behavior," Academy of Management Journal, Vol. 36, No. 3, 1993, pp.527-556.

53. Organ, D. W., Organizational Citizenship Behavior: The Good Soldier Syndrome, Lexington, MA : Lexington Books, 1988.

54. _ \& Konovsky, M., "Cognitive Versus Affective Determinants of Organizational Citizenship Behavior," Journal of Applied Psychology, Vol. 74, No. 1, 1989, pp. 157-164.

55. _ _The Motivational Basis of Organizational Citizenship Behavior," Research in Organizational Behavior, Vol. 12, 1990, pp.43-72.

56. _ _ _ _Organizational Citizenship Behavior: It's Construct Clean-up Time," Human Performance, Vol. 10, No. 2, 1997, pp.85-97.

57. O'Reilly, C. \& Chatman, J., "Organizational Commitment and Psychological Attachment: The Effects of Compliance, Identification, and Internalization on Prosocial Behavior," Journal of Applied Psychology, Vol. 71, No. 3, 1986, pp.492-499.

58. Orr, J. M., Mercer, M., Sackett, P. R.. "The Role of Prescribed and Nonprescribed Behaviors in Estimating the Dollar Value of Performance," Journal of Applied Psychology, Vol. 74, No. 1, 1989, pp.34-40.

59. Patchen, M., "Models of Cooperation and Conflict: a critical review," Journal of Conflict Resolution, Vol. 14, No. 3, 1970, p389-407.

60. Perrucci, R. "Embedded Corporatism: Auto Transplants. the Local State and Community Politics in the Midwest Corridor," Sociological Quarterly, Vol. 35, No. 3, 1994, pp.487-505.

61. Podsakoff, P. M., Ahearne, M. \& MacKenzie, S. B., "Organizational Citizenship Behavior and the Quantity and Quality of Work Group Performance," Journal of Applied Psychology, Vol. 82, No. 2, 1997, pp.262-270.

62. MacKenzie, S. B., An Examination of the Relative Impact of Objective Productivity and Organizational Citizenship Behaviors on Managerial Evaluations of Productive Workers, Working Paper, Indiana University, 1992.

63. _ MacKenzie, S. B., "Organizational Citizenship Behaviors and Sales Unit Effectiveness," Journal of Marketing Research, Vol. 31, No 3, 1994, pp.351-363. 
64. _ MacKenzie, S. B., \& Hui, C., "Organizational Citizenship Behavior and Managerial Evaluations of Employee Performance: A Review and Suggestions for Future Research," Research in Personnel and Human Resources Management, Vol. 11, 1993, pp.1-40.

65. Polanyi, K., The Great Transformation, Beacon Press, Boston, 1957.

66. Porter, L. W. \& Lawyer, E. E., Managerial Attitudes and Performance, Homewood III: Richard D, Irwin.

67. \& \& Steers, R. M., "Organizational, Work and Personal Factors in Employee Turnover and Absenteeism," Psychological Bulletin, Vol. 80, 1973, pp.151-176.

68. $\quad$ Price, J. L. \& Mueller, C. W., Professional Turnover, Bridgeport, CT : Luce, 1981.

69. Puffer, S. M., "Prosocial Behavior, Noncompliant Behavior, and Work Performance Among Commission Salespeople," Journal of Applied Psychology, Vol. 72, No. 4, 1987, pp.615-621.

70. Reichers, A. E., "A Review and Reconceptualization of Organizational Commitment," Academy of Management Review, Vol. 10, No. 3, 1985, pp.465-476.

71. Rhodes, S. R. \& Steers, R. M., Managing employee absenteeism, Menlo Park, CA : Addison-Wesley, 1990.

72. Rousseau, D. M., "Characteristics of Departments, Positions, and Individuals: Contexts for Attitudes and Behavior," Administrative Science Quarterly, Vol. 23, N0. 4, 1978, pp.521-540.

73. Schnake, M., "Organizational Citizenship: A Review, Proposed Model, and Research Agenda," Human Relations, Vol. 44, No. 7, 1991, pp.735-759.

74. Seashore, S. E. \& Yuchtman, E.. "Factorial Analysis of Organizational Performance," Administrative Science Quarterly, Vol. 12, No. 3, 1967, pp.337-355.

75. Smith, C. A., Organ, D. W., \& Near, J. P., "Organizational Citizenship Behavior: Its Nature and Antecedents," Journal of Applied Psychology, Vol. 68, No. 4, 1983, pp.653-663.

76. Steers, R. M. Mowday, R. T., "Employee Turnover and Post-decision Accommodation Processes," Research in Organizational Behavior, Vol. 3, 1981, pp.235-281.

77. Tajfel, H., "Social Psychology of Intergroup Relations," Annual Review of Psychology, Vol. 33, 1982, pp.1-39.

78. Tett, R. P. \& Meyer, J. P., "Job Satisfaction, Organizational Commitment, Turnover Intention and Turnover: Path Analyses Based on Meta- Analytic Findings," Personnel Psychology, Vol. 46, No. 2, 1993, pp.259-293.

79. Tsui, A. S., "Personnel Department Effectiveness: A Tripartite Approach," Industrial Relations, Vol. 23, No. 2, 1984, pp.184-197.

80. Uzzi, B., "Social Structure and Competition in Interfirm Networks: The Paradox of Embeddedness," Administrative Science Quarterly, Vol. 42, 1997, pp.35-67.

81. Van Dyne, L., Graham, J. W. \& Dienesch, R. M., "Organizational Citizenship Behavior: Construct Redefinition, Measurement, and Validation," Academy of Management Journal, Vol. 37, No. 4, 1994, pp.765-802.

82. _ Cummings, L. L., Parks, J. M., "Extra-Role Behaviors: In Pursuit of Construct and Definitional Clarity (A Bridge Over Muddied Waters)," Research in Organizational Behavior, Vol. 17, 1995, pp.215-285.

83. Van Scotter, J. R., Motowidlo, S. J., "Interpersonal facilitation and job dedication as separate facets of contextual performance," Journal of Applied Psychology, Vol. 81. No. 5, 1996, pp.525-531.

84. Williams, L. J. \& Anderson, S. E., "Job Satisfaction and Organizational Commitment as Predictors of Organizational Citizenship and In-Role Behaviors," Journal of Management, Vol. 17, No. 3, 1991, pp.601- 617.

85. _ Podsakoff, P. M. \& Huber, V., "Leader Behaviors, Role Stress, and Satisfaction as Determinants of Organizational Citizenship Behaviors: A Structural Equation Analysis with Cross Validation," A Paper Presented at the Annual Academy of Management Meeting, 1986, Chicago.

86. Xiao-Ping Chen, Hui C., Sego, D. J., "The Role of Organizational Citizenship Behavior in Turnover: Conceptualization and Preliminary Tests of Key Hypotheses," Journal of Applied Psychology, Vol. 83, No. 6, 1998, pp.922-931. 
NOTES 